\title{
S100 negative granular cell tumor of the oral cavity: dermoscopy and surgical approach*
}

\author{
Hernan Mejía ${ }^{1}$, Maria Fernanda Ordóñez Rubiano ${ }^{1}$, Victoria Lucia Dávila Osorioํ, Maria Isabel González ${ }^{2}$
}

DOI: http:/ / dx.doi.org/10.1590/abd1806-4841.20197442

\begin{abstract}
We report the case of a 47-year-old male patient with S100 negative granular cell tumor of the oral cavity, focusing on dermoscopic features as well as surgical approach, not previously reported in the literature. The study contributes to the literature on dermoscopy and surgical treatment for this tumor and provides a practical approach to differentiating non-neural granular cell tumors and granular cell tumors.
\end{abstract}

Keywords: Dermoscopy; Granular cell tumor; Surgery, oral

\section{INTRODUCTION}

Granular cell tumors (GCT), also known as Abrikossoff tumors, are uncommon benign neoplasms probably derived from Schwann cells. They are usually located in the oral mucosa, specifically the tongue. ${ }^{1}$ Non-neural granular cell tumor (NNGCT) is a rare and recently described tumor. Only five cases have been reported with involvement of the oral mucosa, with no reports of dermoscopy or surgical treatment. The current case report contributes to the literature on dermoscopy and surgical management of this tumor and provides a practical approach to differentiating between non-neural granular cell tumors and granular cell tumors.

\section{CASE REPORT}

A 47- year- old male patient presented with a 5-month history of a rapidly growing solitary lesion on the mucosa and semimucosa of the lower lip. Physical examination showed a painful sol- id exophytic bleeding ulcerated pink tumor measuring 12x13mm, with telangiectasias and yellowish hue in the center involving the mucosa, semimucosa, and linea alba of the left third of the lower lip (Figure 1A). Dermoscopy showed a structureless heterogeneous yellowish and white central zone and an apple jelly hue in the lower lateral portion of the tumor with multiple polymorphous vessels in the periphery (dotted, coiled, and looped) (Figure 1B). Histological examination revealed an exophytic ulcerated lesion consisting of cells with granular cytoplasm and homogeneous nuclei with low mitotic rate and no cellular atypia, located on the lamina propria and with skeletal muscle infiltration, without lymphatic involvement. (Figure 2A). On immunohistochemistry, the lesion was negative for S100, CD57, EMA, CD34, and neuron-specific enolase and positive for vimentin, CD68, and calretinin, weakly positive for CD56, with Ki67 proliferation index of approximately 3\% (Figure 2B and 2C).

Received 27 July 2017.

Accepted 21 February 2018.

* Work conducted at the Department of Dermatology, Hospital Militar Central, Universidad Militar Nueva Granada, Bogotá, Colombia. Financial support: None.

Conflict of interest: None.

Department of Dermatology, Hospital Militar Central, Universidad Militar Nueva Granada, Bogotá, Colombia.

Department of Pathology, Hospital Militar Central, Universidad Militar Nueva Granada, Bogotá, Colombia.

MaILING AdDREss:

Victoria Lucia Dávila Osorio

E-mail: victoria15_davila@hotmail.com

(C)2019 by Anais Brasileiros de Dermatologia 

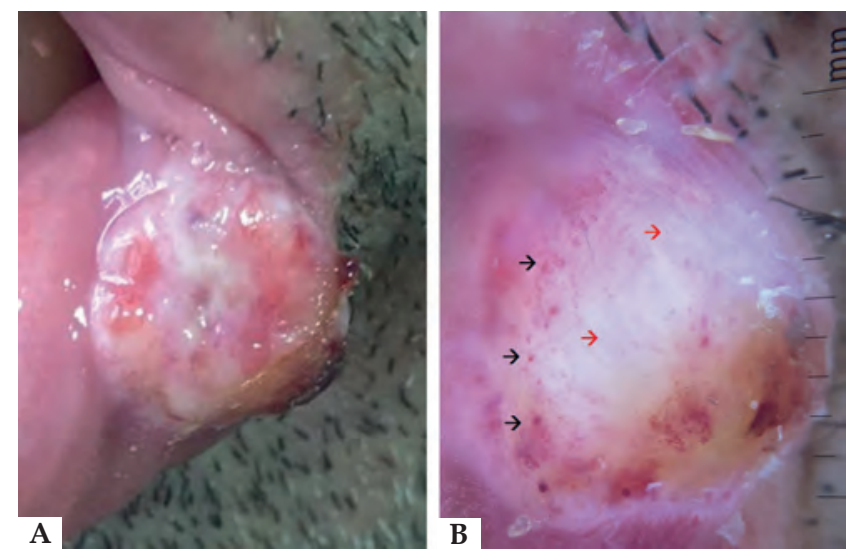

Figure 1: A - Exophytic tumor on the lower lip. B - Dermoscopy: structureless white yellowish zone (red arrow) and polymorphous vessels (black arrows)
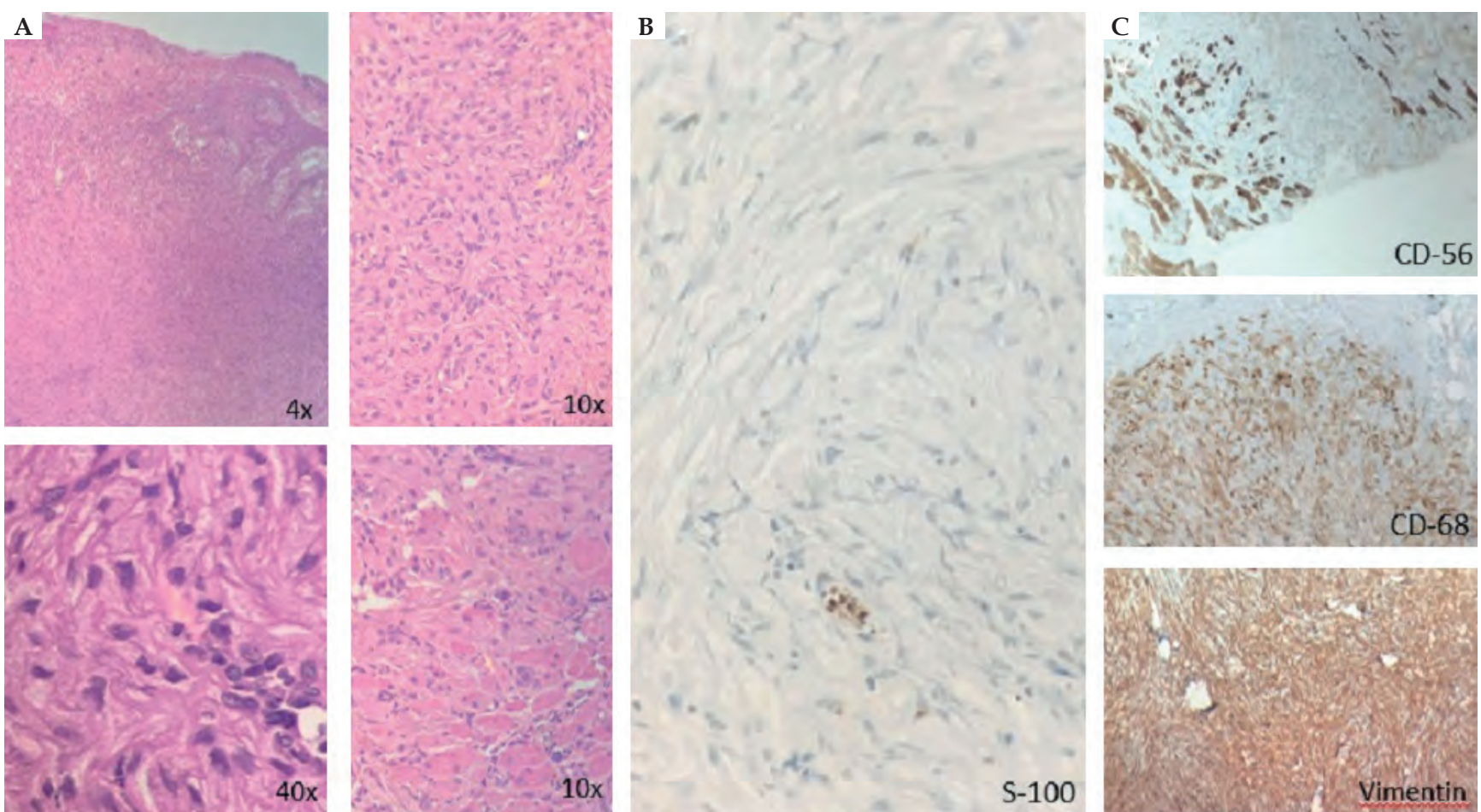

FIGURE 2: A - Histology showing granular cell tumor and infiltration of skeletal muscle on different magnifications (Hematoxylin \& eosin, x4, x10, and x40). B - Immunohistochemistry showing negative S100 staining C - Tumor cells positive for CD56, CD68 e vimentin
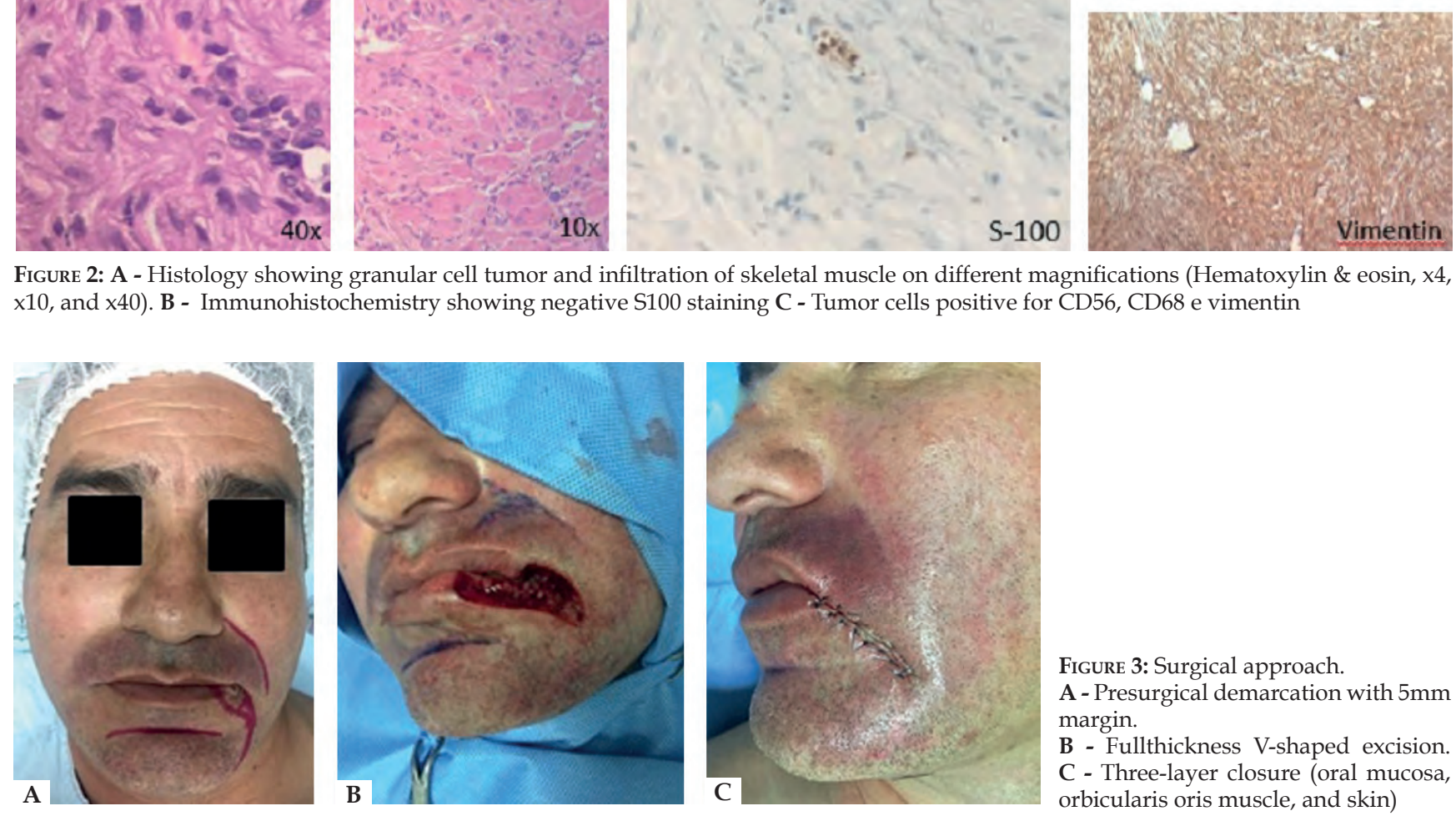

Based on these findings, a diagnosis of non-neural granular cell tuof a full-thickness V-shaped excision with a $5 \mathrm{~mm}$ margin under tumescent anesthesia. A 3-layer closure (oral mucosa, orbicularis oris deep margins were clear (Figure 3). After one year of follow-up, no evidence of recurrence or metastasis was seen. 
TABLE 1: Differences between granular cell tumor and non-neural granular cell tumor

$\begin{array}{lll}\text { Characteristic } & \text { GCT } & \text { NN-GCT } \\ \text { Clinical examination } & & \\ \text { Location } & \text { Head and Neck } & \text { Entire body } \\ \text { Oral cavity } & \text { Common } & \text { Uncommon } \\ \text { Number } & \text { Solitary } & \text { Solitary } \\ \text { Histology } & & \\ \text { Architecture } & \text { Polypoid } & \text { Polypoid } \\ \text { Level of involvement } & \text { Dermis, adipose } & \text { Papillary dermis } \\ & \text { tissue, muscle } & \\ \text { Pseudoepithelioma- } & +++ & + \\ \text { tous hyperplasia } & & \\ \text { Delimitation } & +/- & + \\ \text { Cytologic atypia } & +/- & +/++ \\ \text { Mitotic activity } & - & ++ \\ \text { Pustulo-ovoid bodies } & + & ? \\ \text { of Milian } & & \\ \text { IHC reactivity } & & + \\ \text { S-100 } & + & + \\ \text { Vimentin } & + & + \\ \text { CD68 } & -(71 \%) & + \\ \text { Calretinin } & + & +\end{array}$

* however positive in the present case

\section{DISCUSSION}

NNGCT or S100 negative granular cell tumor is one of the tumors of the oral cavity histologically composed of granular cells. ${ }^{2}$ Histologically, GCT and NNGCT are indistinguishable, and they are usually differentiated by immunohistochemistry. ${ }^{3}$ However, there are some clinical, histological, and immunohistochemical differences that may help distinguish between these unusual tumors (Table 1). ${ }^{2,4}$ As recently described, the NNGCT IHC profile is not well defined; however, vimentin and CD68 positivity is well established. ${ }^{3}$ In the literature, the only five cases of this tumor in the oral cavity report surgical excision as the treatment of choice, but there are no details on margins or any suggested surgical approach. . $3,3,6^{2}$ Full-thickness $\mathrm{V}$ excision with $5 \mathrm{~mm}$ margin and primary closure is a feasible approach with excellent functional and cosmetic results as observed in our patient.

NNGCT dermoscopy had never been reported before. Polymorphous vascular structures in the periphery such as dotted, coiled, and looped vessels and structureless yellowish zone were some of the findings observed in the tumor dermoscopy, similar to those in cutaneous GCT.7 Additional dermoscopy reports are needed to better characterize this type of tumors and possibly define dermoscopic characteristics that could guide the clinician to an accurate clinical diagnosis.

\section{REFERENCES}

1. Plantier F. Granular cell tumour or Abrikissoff's tumour. Ann Dermatol Venereol. 2013:140:399-402.

2. Solomon LW, Velez I. S-100 Negative Granular Cell Tumor of the Oral Cavity. Head Neck Pathol. 2016;10:367-73.

3. Basile JR, Woo SB. Polypoid S-100-negative granular cell tumor of the oral cavity: a case report and review of literature. Oral Surg Oral Med Oral Pathol Oral Radiol Endod. 2003:96:70-6.

4. Torrijos-Aguilar A, Alegre-de Miquel V, Pitarch-Bort G, Mercader-García P, ForteaBaixauli JM. Cutaneous granular cell tumor: a clinical and pathologic analysis of 34 cases. Actas Dermosifiliogr. 2009;100:126-32.

5. Lerman M, Freedman PD. Nonneural granular cell tumor of the oral cavity: a case report and review of the literature. Oral Surg Oral Med Oral Pathol Oral Radiol Endod. 2007;103:382-4.

6. Rawal YB, Dodson TB. S-100 Negative Granular Cell Tumor (So-called Primitive Polypoid Non-neural Granular Cell Tumor) of the Oral Cavity. Head Neck Pathol. 2017:11:404-12.

7. Popadić M. Dermoscopy of cutaneous Abrikossoff tumor (granular cell tumor) in a pediatric patient. J Am Acad Dermatol. 2015;73:e137-8.

\section{AUTHORS'CONTRIBUTIONS}

Approval of the final version of the manuscript; Elaboration and writing of the manuscript; Effective participation in research orientation; Intellectual participation in propaedeutic and/ or therapeutic conduct of the cases studied; Critical review of the manuscript

Maria Fernanda Ordóñez Rubiano

\section{iD ORCID 0000-0002-9802-7978}

Approval of the final version of the manuscript; Elaboration and writing of the manuscript; Obtaining, analyzing and interpreting the data; Effective participation in research orientation; Intellectual participation in propaedeutic and/or therapeutic conduct of the cases studied; Critical review of the literature; Critical review of the manuscript

Victoria Lucia Dávila Osorio

(iD) ORCID 0000-0001-9456-6299

Approval of the final version of the manuscript; Elaboration and writing of the manuscript; Obtaining, analyzing and interpreting the data; Intellectual participation in propaedeutic and/ or therapeutic conduct of the cases studied; Critical review of the literature; Critical review of the manuscript

Maria Isabel González $\quad$ (iD) ORCID 0000-0003-1743-2005

Approval of the final version of the manuscript; Elaboration and writing of the manuscript; Obtaining, analyzing and interpreting the data; Intellectual participation in propaedeutic and/ or therapeutic conduct of the cases studied; Critical review of the manuscript

How to cite this article: Mejía H, Ordóñez Rubiano MF, Dávila Osorio VL, González MI. S100 negative granular cell tumor of the oral cavity: dermoscopy and surgical approach. An Bras Dermatol. 2019;94(1):79-81. 